\title{
Binarism, Identity (Crisis) and Power Structures in Postcolonial Anglophone Fiction: Analyzing Discursive Strategies in The God of Small Things
}

\author{
Sundas Tahreem ${ }^{1}$, Inayat Ullah ${ }^{1} \&$ Tariq Khan ${ }^{2}$ \\ ${ }^{1}$ Department of English, National University of Modern Languages (NUML), Islamabad, Pakistan \\ ${ }^{2}$ Department of English, University of Malakand, Khyber Pakhtunkhwa, Pakistan \\ Correspondence: Inayat Ullah, Department of English, National University of Modern Languages (NUML), \\ Sector H-9, Islamabad, Pakistan. E-mail: inayat_ktk@yahoo.com
}

$\begin{array}{lr}\text { Received: April 8, } 2020 & \text { Accepted: June 25, } 2020 \quad \text { Online Published: July 8, } 2020 \\ \text { doi:10.5539/ijel.v10n5p100 } & \text { URL: https://doi.org/10.5539/ijel.v10n5p100 }\end{array}$

\begin{abstract}
Binary relationship among people of a particular society creates a power correlation that becomes a common social practice of that society with the passage of time. Social structure is based on power structure of any society that defines social identities on the basis of collective social ideology. The present study is based on Fairclough's approach to Critical Discourse Analysis (CDA) that takes discourse as social practice. In this study, an effort has been made to show how social practices create power imbalance in the society. The objectives include study of binary relationships that establish power relationships, role of power structures to define social identities, role of ideology to maintain power and hegemony in social structures and to bring into the limelight the resistance of oppressed class against power structures. The study is delimited to the novel, The God of Small Things by Arundhati Roy, and Postcolonial binarism is applied for analysis of the text. Binary relationships of the society have been exclusively studied through Fairclough's approach to CDA. The analysis shows that social identities are ideologically driven on the basis of power relationships and it is due to ideological construction that certain group of people sets up hegemony and dominated group gives its consent to dominant group. Firstly, discourse forms knowledge which defines social relationship. Secondly, ideology is constructed due to power relationships. Lastly, social roles construct social identities on the basis of ideology. Roy also has created some economically weak and socially marginalized characters in her novel which try to go against established social practices to bring disorder in the hierarchy of social structure. The study has research implications for the fields of Language and Literature as the evaluation deals with the exploration of a literary text through the lens of the theories of language and literature. Researchers can also further the scope of the present study by conducting an exclusive and comprehensive study of the selected novel on marginalization of women in the given society.
\end{abstract}

Keywords: critical discourse analysis, postcolonialism, binarism, identity, ideology, resistance

\section{Introduction to the Study}

The present research is designed to analyze social practices and social structures that create power imbalance and binary relationships among people on the basis of caste and gender. Fairclough's approach to Critical Discourse Analysis (CDA) that discuses discourse as a social practice is applied for the analysis. The analysis of the text traces out the power imbalance created by power structure in the society that defines social identities on the basis of existing ideologies of the people of the town, Ayemenem in India. The research is designed to examine power relationships on the basis of gender, caste, economy, politics and culture of Ayemenem. The analysis shows that social identities are ideologically driven on the basis of power relationships and it is due to ideological construction that certain group of people sets up hegemony and dominated group gives its consent to dominant group. Fairclough asserts that there is always a chance that oppressed group of people may resist against defined social identities. The analysis shows some of the major characters of the novel resist against established social identities and power structures of the society.

The significance of this research paper lies in the fact that the analysis of the paper is based on Fairclough's approach to CDA with a Postcolonial perspective that is unique in its approach. This analysis of the novel, The God of Small Things is also significant in the sense that the issue of bianrism has always been there in these 
previously colonized society. This is how these societies carry the power structure that is based on the identity development of the marginalized segments of the society as people who accept their weaker status as it is. The study is also important as it endeavors to highlight the discursive practices used for this purpose. In this particular case, the analysis highlights social practices and social structures of an Indian town, Ayemenem on the basis of binary relationships among the people. One way or the other, the social structures as well as the operations of power paradigms work on the same wavelength throughout the world. This is how the weaker segments of the society are made to believe that this is what their status is in the society, and that this is what their actual place must be in the society. The study brings forth the functioning of these social structures which are based on the principle of binarism.

The study is delimited to the novel, The God of Small Things (2001) by Arundhati Roy. Critical Discourse Analysis and Postcolonial theory are applied to study the novel. This has been further delimited to Fairclough's approach to CDA and the subject of binarism for the analysis of the text. The issue of binarism creates power imbalance in the society and one object (group) in binary relationship dominates the other object (group). The study focuses on binaries such as dominate/dominant, oppressor/oppressed, man/woman and weak/powerful. The analysis shows that binarism establishes hegemony and the dominant entity exercises power on the dominated entity and the later cannot resist most of the times because of the persistent social ideology.

The God of Small Things (2001) presents social structures and social practices that create power imbalance in the society and a specific group of people dominates the other groups on the basis of power relationship. The novel exhibits that social practices constitute social identities defined by social ideologies that set up norms for the people to behave in a particular manner. Social inequality and power imbalance in the novel are presented on the basis of caste system, class system and gender discrimination. The dominant class of people is shown to oppress and marginalize the weak class of the society to maintain power and hegemony in Ayemenem. This dominance extends to economy, politics and culture of the town as a whole. The dominance on the basis of gender, in the novel creates patriarchy in the society and women in the story are marginalized by men both in the household and at the workplaces.

\section{Research Questions}

The study endeavous to answer the following research questions:

1) How is binarism created in the selected literary text to establish dominance in social practices?

2) What is the role of ideology to obtain and maintain power and hegemony in defining social identities in the social structure of Ayemenem town?

3) How is resistance presented against established power structures of the town in the selected literary text?

\section{Literature Review}

Jorgensen and Phillips (2002) assert that Norman Fairclough views discourse as social practice and he proclaims that discourse transforms and reproduces social relationships and social identities. These social identities and social relationships are generated by power structures in the society. He considers text and its context as phenomena which have a very strong relationship and the text cannot exist in isolation because it has roots in a particular society. He takes discourse as social practice and his approach to discourse is highly text oriented. Language is an important element of critical discourse analysis and Fairclough asserts that language has three dimensions: text, discursive practice and social practice. When he says that language is a text it means spoken and written language as well as visual images. Language as discursive practice involves production and usage of text Language and social practice means language use in socio-cultural aspect that involves economics, politics and culture.

Adli Jacobs writes in his essay, Overview of Critical Discourse Analysis that Fairclough's approach to CDA has three-dimensional framework. The first dimension is about the text that can be in the form of written or spoken language or it can be a visual image. The focus remains on the text and it is observed that who is talking to whom. The second dimension is about discursive practice and it is seen and analyzed how are power relations shown in the text and how has discourse worked to establish power structure in the society. The third dimension is broad and it focuses on social context of the text and socio-political and socio-cultural aspects are emphasized.

Wodak and Mere (2001) state that social life is a network of social practices and these social practices are economic, political and cultural in nature. Social practice is defined by permanent social actions in relation to a structured chain of social practices. Language is a social phenomenon and it indicates social positions of individuals, institutions and social groups. Language is an important element of discourse and it is used as a tool to exercise power in the society. Power is exercised with a relation to difference in a particular society. Norman 
Fairclough takes Marxist perspective and studies discourse in relation to dominance, difference and resistance. $\mathrm{He}$ analyses social practices in relation to social identities, social differences and cultural values.

From the relation of difference and power, certain ideologies are constructed in the society. Fairclough takes ideology as 'meaning in the service of power'. Dominance is based on social structures which promotes gender discrimination and class difference in the society. He views discourse as ideological driven and it helps to maintain power structures in the society. He further says that there is always a possibility that dominated class may resist against these power structures, even if there is not sufficient awareness in them about ideological scope of the social practices. Discursive practices of a given society can be studied with the help of certain hegemonic structures as hegemony is exercised on weak class of the society using power by the dominant class and discursive change can only take place if the discursive elements start acting in a new and different way (Jorgensen \& Phillips, 2002).

Fairclough takes politics as an important element of social practice and it is responsible for existential issues and public agenda. Chouliaraki and Fairclough (1999) write in their book that politics focuses on actions of individuals that help to originate social actions in a given society and in the modern times, people have started to resist against established social structures that are controlled by dominant class. This is the same resistance addressed by Fairclough that has been discussed by Jorgensen and Phillips in their book. Fairclough states that resistance is likely to occur in a given society against the power structures. Economy, politics and ideologies are based on hegemony of dominant classes of the society and these dominant classes set up a difference among social classes. Power is exercised in all the social institutions including family, school, workplace and neighborhood. The dominant classes in the society not only exercise power on the dominated class but they also win their consent to accept them as powerful and they let them dominate and maintain power structures in the society but at the same time there is always a chance of resistance from this dominated class. At times, there is some change in expected discursive practices and this change can be seen in the form of difference in the prescribed gender roles and the reversal of these gender roles in the society. Sometimes, political practices also change with the rise of different movements at different times that work against discursive practices.

Fairclough (1989) asserts that discourse has two aspects of power relationships. The first is power in the discourse and the other is power behind the discourse. Power in the discourse means face to face spoken discourse between the people of two ethnic or social groups in which power is directly practiced. In this regard, he gives an example of a class of medical students with a doctor. He analyses their speech in terms of power relationship. The doctor is at a powerful position that is why he interrupts his students time and again. It is not just he wants to talk most of the time during that particular session but because he wants to control the whole discussion. So, he interrupts his students and the students know social power structure and that is the reason that they are not shown to interrupt the doctor and even when the doctor interrupts them they stop speaking at once.

Power behind the discourse means the whole social structure and social practices that take place under the influence of hidden powers of dominance. Patients are controlled by medical staff. Patients are made to do certain things by medical staff and they behave the same as they are instructed. The actions of the patients are controlled by the medical staff and this medical staff is also controlled by those who are higher in hierarchy in that particular institution. So, there is a power structure that controls the social practices and makes the dominated class behave in a particular manner because of ideological interference. Ideologies make both dominant and dominated classes to behave in a prescribed manner and this ideology itself is created by powerful group of the people (Fairclough, 1989).

Rabindranath S. Polito (2001) proclaims in his article that discourses show themselves in language use and the language presents imbalance, inequality and injustice in a particular society. He further refers to Fairclough's outlook that discourse is a social practice and it creates the common sense assumptions of the people driven by ideology that is made by relations of power. Gee and Green (1998) write in their article that discourse is a socio-cultural practice and discourse analysis tells about cultural practices and established meanings behind certain situations. Robyn Henderson (2005) states in his research paper that Fairclough's approach to CDA constructs a relationship between discourse and society, text and context and language and power. Moslem Ahmadvand (2011) asserts in his article that Fairclough believes that discourse is social practice and language shapes the identity of the people in a society and his approach helps to create awareness among the people about power relations in the society.

Fairclough and Isabela (2008) inscribe about the state Romania and in the research paper and prove that gender relationships are also power oriented and patriarchy is of three types: traditional patriarchy, state patriarchy and capitalist patriarchy. Traditional patriarchy is about household. In this type of patriarchy, we see the 
marginalization of women inside the home. State patriarchy is based on economy and it emerged during communist period, in which salaries of men were higher than the salaries of women, and men were given maximum jobs in the public sectors and majority of working women had jobs in private sectors. Capitalist patriarchy emerged after 1989 when new elite emerged in the society and wealth and power was controlled by them. The elite were excluded by women from the top positions in politics and economy.

\section{Theoretical Framework}

Postcolonial theory studies the effects of colonization on societies, which were colonized in the past. It challenges hegemony and the controlling power of the dominant group countries (colonizers). Postcolonial scholarship became deeply concerned with politics, culture, patriarchy and economy with the independence of the earlier colonized nations. In this context, binarism is a very important issue in postcolonial studies. The concept of binarism was first established by Ferdinand De Saussure, who referred this concept to the signified and the signifier. He argued that the meanings of certain signs are taken not by real objects but they are taken by the relationship of signs to their opposite objects. For example, we can only know the meaning of good when we have a concept of evil (Ashcroft, Griffiths, \& Tiffin, 1998).

Postcolonial studies binary objects in terms of power because the term that has an opposite meaning to the other term creates dominance. One term always dominates its opposite term like man dominates woman, civilized dominates primitive, good dominates evil, advanced dominates retarded Binarism also constructs social ideologies and ideological meanings of binaries in general and this is the reason that men in the society consider themselves dominant and powerful than women and they establish hegemony on the basis of gender to marginalize women (Ashcroft et al., 1998).

Edward Said (1978) notes that discourse and orientalism are generated by power because the people in power generate certain discourse. The genre orientalism itself is the creation of West who has the power to write about East and it has associated certain characteristics about the Orientals (East). The Orientalists (West) have misrepresented the Orientals because they had the power to create specific images about East because being the Orientalists they had the right to research, write and study the Orientals and to represent them the way they wanted. Spivak, in her essay, Can the Subaltern Speak? studies the power relationship between dominant and dominated group of the people in the society. She portrays subaltern's identity in relation to power and discourse. She asserts that a subaltern is always unconscious about his true identity and he cannot represent himself because a subaltern cannot speak. So, the people who dominate him are the ones who represent him. She writes that women are double marginalized in postcolonial countries, where power structures are created. In such societies, power is exercised on dominated subjects because the ideological constructions make the society male dominant society. Here, oppressed men also exercise power on women. This makes a woman subaltern a double marginalized subject (Ashcroft et al., 1998).

\section{Analysis and Discussion}

The God of Small things (2001) is about a small town of India known as Ayemenem. The story centers members of a Syrian Christian family. Mammachi and Pappachi are elders in the family and they have business of a factory that has been established by Mammachi. Their daughter, Ammu leaves the house and marries an alcoholic man. After some years, she divorces her husband and returns to her parents' home with her twins named, Rahel and Estha. She falls in love with Velutha, the untouchable thus she is cursed by the society for loving an untouchable. She dies at the age of thirty-one and the Church denies burying her because she is accused of having physical relationship with an untouchable of the society. Chacko, the son of Mammachi and Pappachi and the brother of Ammu, goes to Oxford University to study and marries Margaret but after the birth of a daughter, she divorces him to marry another man. On his return to Ayemenem, Chacko joins a local political party and develops terms with a communist leader Pillai. After the death of Margaret's second husband, she visits Ayemenem on Chacko's request to see him but unfortunately, her daughter, Sophie dies while rowing with Ammu's twins. Velutha, the untouchable, is given a job at the factory that is established by Mammachi but run by Chacko. Velutha is also a member of local political party but unfortunately, he is accused of the death of Sophie and kidnapping of the twins with the conspiracy of Baby Kochama, the sister of Pappachi and Aunt of Ammu and Chack. Velutha is killed in the custody because of brutal physical torture by policemen.

The entire novel revolves around the binary relationships that create dominance and power imbalance among the people in Ayemenem. Arundhati Roy emphasizes on caste system in Ayemenem with special reference to the protagonist of the story, Velutha, The God of Small Things is representative figure of India in this regard where discursive practices are strictly followed by the people. Roy's God of Small Things (Velutha) being an untouchable, is at the bottom of hierarchy of caste system in the social structure of Ayemenem town. Roy 
narrates historical background of untouchables to highlight discursive and social practices of the town. Untouchables are considered out of the caste and they are supposed to clean washrooms and public roads. This is the social role of untouchables which is defined by discursive practices of the town. As per the discursive practices highlighted in the novel the Untouchables are not given any other jobs except cleaning but Velutha is privileged in this regard as he is presented to have a job as a carpenter at Paradise Pickles and Preserves factory which is established by Mammachi and presently, is run by Chacko. Roy's choice of Velutha's profession clashes with his established social role being an untouchable.

Velutha was not supposed to be a carpenter. Velutha would come to the back entrance of Ayemenen House... Pappachi would not allow Paravans into the house. Nobody would. They were not allowed to touch anything that touchables touched... Paravans were expected to crawl backwards with a broom, sweeping away their footprints so that Brahamns and Syrian Christians would not defile themselves by accidently stepping into a Paravan's footprints (pp. 70-71).

Velutha is fortunate being an untouchable as he was given special favor by Mammachi to work in her factory as well as in her home. She has been in touch with him since his childhood because his father has served Mammachi's family for so many years. Otherwise, the untouchables are treated worse than animals. He was allowed into the house but only through the back entrance to maintain the ideology that the untouchable should not use the same entrance that the touchables use as they are not equal to them. Roy has presented the class and caste discrimination dramatically when she ironically presents Mammachi's generosity in contrast to Pappachi and established discursive practices when she lets Velutha in her home and the factory. She has portrayed an extreme to binary relationship of the powerful and powerless when she narrates the history of Paravans, the untouchables. They were ordered to sweep away their footprints as they walked on the roads, while cleaning those roads to keep the touchables from walking on the footprints of the group of people who were even out of caste and class, the untouchables.

Roy brings into the limelight the social and discursive practices of Ayemenem of subjugation and marginalization of the people who are at the bottom of social hierarchy. She uses Mammachi as her mouthpiece to achieve this goal when she narrates the history of these Paravans. To maintain the hegemony and social discrimination, the powerful class of the town has established discursive practices that define social role of untouchables to behave in a particular manner.

Untouchables were not allowed to walk on public roads, not allowed to cover their upper bodies, not allowed to carry umbrellas. They had to cover their mouths when they spoke to divert their polluted breath away from whom they addressed (p. 71).

The above extract from the text based on social practices tells us about the power structure in the town named Ayemenem in India. Fairclough's three-dimensional model of discourse analysis can be observed in this harsh social reality of this society. The rigid caste system in Ayemenem is presented by the author that establishes power imbalance among the people. The people with high caste are shown to dominate the people of low caste and the powerful people in the society have even deprived a group of people from the honor of having any caste at all in this particular case of the untouchables. They are known as untouchables and they are not allowed to touch the things that the so-called touchable group of people in the society touches. It shows a power structure that establishes power relationships among the people.

The powerful group of people defines social identities, social roles and behaviors in the given society. The untouchable class is suppressed by dominant class in Ayemenem and their hegemony is established because the untouchables are shown to obey them as they have given their consent to the powerful group by accepting their social identities. They are not allowed to walk on public roads and they do not walk on them, they are made to sweep their footprints and they are shown to obey, they are not allowed to cover their upper bodies and they do not cover them, they are forced to cover their mouths as they talk to the touchables to divert their polluted breath and they do as they are instructed because the dominant class in the society has won the consent of this dominated class. The dominated group of untouchables has accepted its social identity because social identities are constructed through ideology of certain group of people in the society. The ideology is also constructed by powerful and dominant group of people about social relationships and social roles so that is why dominant and powerful people make dominated and weak class of people to behave in a certain manner and to act according to their established social identities. This ideology among the oppressed untouchable makes them obey the oppressors because they believe that they are born to be marginalized.

Arundhati Roy further traced out the history of this oppressed class of untouchables that at the arrival of British colonizers to Malabar, some untouchables converted to Christianity to escape from the horrors of inequality in 
social relationships and social injustice but they were given the title of Rice Christians "and therefore casteless" (p. 71). Separate schools and churches were made for them and after the independence, they were not given government jobs and bank loans being Rice Christians.

It did not take them long to realize that they had jumped from the frying pan into the fire... It was a little like having to sweep away footprints without a broom. Or worse, not being allowed to leave foot prints at all (p. 74).

Above excerpt from the novel shows that dominant and powerful class in the society never allows the weak ones to rise in social position because their social positions define their social identities. Let us not forget that the dominant class always wants to enjoy hegemony over the weak and oppressed class. Roy harshly criticizes social practices of Ayemenem which deprive human beings from their basic rights. Untouchables in her novel are treated worse than animals due to discursive practices that lay down the rules based on hegemony and dominance within a society. The ideology of the society which is again created by the powerful group of the people is responsible for creating binary opposites in Ayemenem. The binary relationship among the people has decided that all the people of the society are not equal resulting in the demand of separate schools and churches for the touchables and the untouchables.

The binary relationship is also established on the basis of gender where women are dominated by men in social structure of Ayemenem. Women are presented as weak, dominated and oppressed at household as well as at the work place. They are marginalized by men at both the places that denotes patriarchal system in Ayemenem. Pappachi, the husband of Mammachi always dominated her and oppressed her physically and mentally. "Every night he beat her with a brass flower vase" (p. 47). There was no resistance from Mammachi as she knew her prescribed social identity of being a woman and being a wife. This social identity has already prescribed her social role to obey her husband and she was supposed remain silent on this brutality of her husband. She founded pickle factory that was expended by her son, Chacko. She worked a lot for this factory despite the fact that she was semi-blind and Pappachi never helped her in making pickles. He did not help her because of his defined social identity of being a husband in a patriarchal society has already prescribed his gender role which did not allow him to help his wife. Mammachi was the founder of the pickle factory and her daughter, Ammu also helped her in factory affairs but Chacko, the son of Mammachi, took all the credit and referred all the things to his own property.

My factory, my pine apples, my pickles, Chacko said, 'what's your is mine and what's mine is also mine. Legally, in this case, because Ammu, as a daughter had no claim to the property... Ammu had no Locusts Stand I (no legal standing) ... Thanks to our wonderful male chauvinist society (p. 56).

Roy clinically presents social and discursive practices of Ayemenem to bring into the limelight the curse of patriarchy resulting in injustice in the property rights of the women. There is no legal right of daughter in property of his father because it was a male dominated society. Women are shown to be marginalized by men not only at home but at the work place as well. Chacko ran the factory and called beautiful women who worked in his factory to flirt with them. He had power to exploit those women with money and those women needed the money and they could not resist against his sexual harassment because they were weak, being women and being from a lower class, hence, double marginalized. He used to cast an evil eye on them to exercise his power on them. "He forced them to sit at table with him and drink tea" (p. 65). Ammu did not like Chacko's manipulation of factory workers on the basis of gender and class. Here. Roy uses Ammu as her mouthpiece to convey to her readers, "the old zamindaar mentality - a landlord forcing his attentions on women who depend on him for their livelihood" (p. 62).

The problem with these subaltern entities is not only their inability to speak against him and to record their resistance but the real problem is the warning against the essentialist notion regarding the defined identity of a female subaltern by the powerful patriarchal system. The very term woman with its binary object man declares dominance and hegemony of men over women. Those working women gave their consent to dominant and powerful boss, Chacko because they were double marginalized on work place due to social structure and their defined identity as weak, oppressed and dominated subjects. They are marginalized at factory for the two reasons: the first one is simply because they are women and the second one is that they are employees of Chacko and he is on a powerful position in the society being a man and as a boss in the factory. They are not only subaltern entities being women, but they also work under him being his employees that makes them double marginalized by the social structure of patriarchy. The powerful group of the people has created ideology that has defined their social identity as being weak, dominated and oppressed by powerful, dominant males in the society. The question that Spivak has raised in her essay, Can a Subaltern Speak? has been answered by Roy. The answer is "No". As social and discursive practices do not allow these doubly marginalized women to raise their voices 
against men in the patriarchal society.

Ammu, the touchable, developed physical relationships with an untouchable named Velutha and when Mammachi comes to know about it, she strongly opposes this relationship and curses her daughter that highlights social practices based on caste hierarchy in Ayemenem. She did not accept the affair of her daughter as Roy presents Mammachi's discrimination between her own children on the basis of gender, "her tolerance of men's needs as far as his son was concerned became a fuel for furry at her daughter" (p. 244). On the contrary, she encouraged illegitimate physical relationships of her son with his employees. She made a separate entrance for the convenience of Chacko at home to enter with the women who worked in his factory and she called it "Man's Needs". Baby Kochama tells her about illegitimate relationships of Chacko and she replies "He can't help having a man's needs" (p. 160). It shows that men have all the rights to do whatever they want to do and that is acceptable in the society but women are not allowed to do those things because they are oppressed, marginalized and dominated group of the society. This is because of the defined gender roles by discursive practices in Ayemenem.

Roy exposes economic and political stance of oppressed subjects in the social structure of Ayemenem. The untouchables are oppressed economically by dominant group of people. They are not supposed to do public or private jobs because they are not supposed to sit and work with the people belonging to high caste and class. So, they are supposed to have only cleaning jobs. They are suppressed economically so that they can never upgrade themselves, it shows that dominant group of people want to maintain their hegemony over them. Roy tells her readers that the powerful class of the society decides ways of life to maintain and legitimize their hegemony. Fictional town of Roy's novel has prescribed social structure and on the basis of that structure, social practices have been highlighted. There are prescribed social identities and on the basis of these identities, their roles are defined. There are fixed professions for the touchables and for the untouchables and they also have separate schools to further reinforce hegemonic structure. Since he was intelligent and since his childhood, "Mammachi persuaded Vellya Paapen to send Velutha to untouchables' school" (p. 71). She continues with the same subject, "Velutha had a way with machines. Mammachi (with her imperial touchable logic often said that if only he had not been a Paravan, he might have become an engineer" (p. 72). Apart from untouchables, women are also oppressed economically because they have no right to claim the property of their fathers and the female workers at pickle factory are shown to work equally with men but their wages are less than men only because this is patriarchal society that has already set an ideology about defined identities on the basis of gender so women have no right to get equal salary to men.

Roy also highlights the social stance of the oppressed group in the politics. The dominance and oppression are highlighted on the basis of gender and caste system by the cultural model of Ayemenem. It is shown in the novel that there is a local communist party and Pillai is the leader of that party. Chacko is also a member but there is not even a single female member in this party that shows women are weak and inferior and they are not supposed to join politics because their roles are settled by the power structure. Then comes the discrimination on the basis of caste system. Velutha is a member of this communist party and it is very ironic that the party always talks about social equality but there is no social equality in the party itself. Velutha was not treated equally. When Baby Kochama created conspiracy and registered a false First Information Report in police station against him, Thomas Mathew came to Pillai and asked for the permission to arrest Velutha. Despite the fact that Thomas Mathew had no evidences against him, Pillai permitted him to arrest him because he was an untouchable and Pillai did not bother to think a good thing about him. He did not want to defend him despite the fact that he was a member of his party but being untouchable, he remained untouchable and discriminated in the party.

The social and discursive practices of Ayemenem in the novel exhibit culture of the town. Ayemenem is presented to be a patriarchal society and male dominance is displayed in all the domains of this society that are mentioned in the text for example at home, workplace and politics. Women are not shown to participate in political affairs or business. They are marginalized and dominated by men at homes and at work places equally. Chacko suffered in his married life because of the patriarchal culture. He was in habit of dominating women and he messed up home and never excused Margaret for that. This behavior teased her the most, despite all the fuss created by Chacko at home he was never sorry for his behavior. He behaved in that particular manner because it was the product of Ayemenem culture that was male dominant society and he never learnt to excuse from a woman.

Divorce is considered very bad in Ayemenem culture and people come to console the family of the woman as a social practice because they take it as a form of death. "Pillai pronounced the word divorce as 'Die-vorce' as if it was a form of death" (p. 130). The divorced women are considered man-less women. A divorced woman is considered to have no place at parents' home as well as anywhere in the society. Love marriages are also not 
acceptable in Ayemenem. The social practices define rules and laws to behave in a particular manner and to do certain things. These social structures are established by powerful and dominant group of people in the society. Roy ironically presents these social practices and power structures because they are merely based on power imbalance and they oppress weak and dominated class of the society. It is very ironic that the socio-cultural practices are defined by powerful group of the people and they not only define social identities and social roles but they also make love laws. It is written about Ammu, Velutha, Estha and Rahel that they all broke love laws because Ammu developed physical relationships with untouchable Velutha and there was an incestuous relationship between Estha and Rahel. "They all crossed into forbidden territory. They all tempered with the laws that lay down who should be loved and how and how much" (p. 31).

Roy demonstrated caste discrimination to highlight socio-cultural practices of Ayemenem. Untouchable is the product of cultural practice that is established and maintained by powerful and dominant group of people who assign them the tag of untouchables and decide dos and don'ts for them. Velutha's father witnessed the physical relationship of Ammu and Velutha and went to Mammachi to tell her the whole story in loyalty and faithfulness that was created by his ideology about the relationships of untouchables and touchable on the basis of power and hegemony. Mammachi became very aggressive and called Velutha's father a dog and called for Velutha. When he arrived at Mammachi's home she spat on his face. This is extreme of caste discrimination on the basis of power relationships that construct social identities, social action and behaviors. She exercised power on untouchables and the social structures that are based on power imbalance legitimized her action to spit on the face of an untouchable. He also did not react on it because his social identity suppressed him and established a hegemonic environment in which Mammachi had a right to release her anger and frustration and Velutha was made to be oppressed and dominated.

The hegemonic patriarchal system is also portrayed in Ayemenem culture. Women are dominated and oppressed by men both at home and work place. Pappachi beats Mammachi every night and she does not resist his beating because she has accepted her social identity of being weak and powerless. She accepts her position at home as oppressed subject because it is not only she who is given beating by her husband but it is story of every woman in that particular town. The ideology of the town's people about patriarchal system makes men to dominate women as they are considered weak in the society. Baby Kochama also knows her position in male dominant society that is why she does not express her love for Father Mulligan. She did not tell him even about her feelings because she knew it was not acceptable for a woman in the society that laid love laws. She secretly loved him all her life and remained in touch with him till his death. She used to express her love regularly for Father Mulligan in her diary. She was also under the influence of hegemonic structure and cultural model of society that do not allow people to do certain things against their defined roles and identities.

There is a social hierarchy of power distribution among the people of Ayemenem. At the top, there are men and those men who are financially strong and have high caste, they dominate whole society and make social structures and define social identities and social roles on the basis of caste and gender. They establish their hegemony generally in the society and specifically at home. Pappachi, Chacko, Pillai and inspector Thomas Mathew (who tortured Velutha to death) are shown to establish hegemonic and power structure in society because they have a high position that makes them powerful in Ayemenem. Pappachi and Chacko have a discriminating attitude towards women and they oppress them. Then there is the place for men from lower social strata in social hierarchy, they are oppressed by dominant high-class men but still they are powerful at their homes and can exercise their power at female members of the family. Kathakali dancers are shown to beat their wives because they consider themselves powerful and their wives are exhibited to confirm this hegemony. Then comes the place for women in social hierarchy who are oppressed by male members in the family but still they have urge to enjoy power so they establish a domestic power hierarchy for example Mammachi and Baby Kochama are elderly women in the family and they develop their hegemony among female members and children in the family. Mammachi could not question Chacko for his illegitimate relationships with female workers but she strongly resisted and interfered in Ammu's relationship with Velutha. Baby Kochama could not do anything for herself because of her social identity and defined social role that did not allow her to announce her love and get married to Father Mulligan. Therefore, she played a role of the villain to separate Ammu from Velutha and made a conspiracy against him that resulted in a false First Information Report against him that led him to death. Ammu was oppressed not only by men in the family but also by Mammachi and Baby Kochama. She could not do anything against her social identity of being oppressed so she established her hegemony on the twins and released her frustration on them by scolding them.

Fairclough proclaims that there is always a possibility of resistance against established social and power structures in the society. Roy presents the same in her novel. Although, characters that are shown to resist against 
hegemonic structure are weak, marginalized and less in number but still they play their role to resist against power structures. Ammu and Rahel divorced their husbands because they did not want to live with them so they took a stand against established discursive practices in Ayemenem where divorce was considered awful but they did not care about that and showed their strength and will power to take a decision that was not a part of their defined social role and identity. Ammu and Velutha broke love laws of social structure of Ayemenem. She indulged in physical relationship with an untouchable that was not allowed by the society. Rahel and Estha also established incestuous relationship that was a taboo and was against social and discursive practices of Ayemenem but they did a rebellious job. These four characters violated social laws of Ayemenem social life that were made by the people in power. Though these defiant characters were weak and marginalized, still they did not conform to hegemonic structures, social and discursive practices of their town.

\section{Conclusion}

Arundhati Roy confirms in her novel, The God of Small Things Fairclough's belief that discourse forms knowledge, defines social relationships and social roles and it constructs social identities on the basis of ideology and it is shaped by relations of power. These power relations create binary relationships among the people. She shows binary relationships on the basis of dominance and hegemony of a patriarchal society of Ayemenem. She exhibits power imbalance on the basis of gender and caste to show the extent to which the weak group of people is oppressed by dominant and powerful group of people on cultural, economic and political level. She also has created some characters in her novel who, despite being weak and marginalized, have tried to go against established social practices and bring disorder in social structures because Fairclough considers that there is always a possibility in a particular society to have some individuals who try to combat against social practices and their defined social identities and social roles. However, most of the characters fall prey to these social structures, where they are usually marginalized by the powerful segments of the society. This is what they start believing as their real place in the society; thus, shaping their identity is that of the marginalized and powerless ones. The same binarism prevails when it comes to the status of women in a patriarchal setup, where women are made to be believe, through discursive practices, as weak and marginalized. This essentialist approach can be challenged through counter discourse, which, due to the prevailing condition of every society that is filled with people believing in this binary relationship, is not easy to achieve.

\section{References}

Ahmadvand, M. (2011). Critical discourse analysis: An introduction to major approaches. Jurnal Ilmiah Dinamika Bahasa dan Budaya, 5(1), 82-90.

Ashcroft, B. (1998). Key concepts in post-colonial studies. London and New York: Rutledge. https://doi.org/10.4324/9780203402627

Ashcroft, B., Griffiths, G., \& Tiffin, H. (1989). The empire writes back. London and New York: Rutledge.

Ashcroft, B., \& Tiffin, H. (1995). Post-colonial studies reader. London New York: Rutledge.

Chouliaraki, L., \& Fairclough, N. (1999). Discourse in late modernity: Rethinking critical discourse analysis. Edinburgh: Edinburgh University Press.

Fairclough, N. (1989). Language and power. New York: Longman Publishers.

Fairclough, N. (1995). Critical discourse analysis: The critical study of language. New York: Longman publishers.

Fairclough, N., \& Ieţcu, I. (2008). Legitimation and strategic maneuvering in the political field. Argumentation, 22(3), 399-417. https://doi.org/10.1007/s10503-008-9088-9

Gee, P. J., \& Green, L. J. (1998). Discourse analysis, learning and social practice: A methodological study. Review of Research in Education, 23, 119-169. https://doi.org/10.2307/1167289

Giles, M. (2011). Postcolonial gothic and the god of small things: The haunting of India's past (vol. 6, pp. 1-15). Ocean County College, New Jersey.

Henderson, R. (2005). A Faircloughian approach to CDA: Principled eclecticism or a method searching for a theory? Melbourne Studies in Education, 46(2), 9-24. https://doi.org/10.1080/17508480509556422

Jorgensen, M., \& Phillips, J. L. (2002). Discourse analysis as theory and method. London: Sage Publication ltd. https://doi.org/10.4135/9781849208871

Polito, S. R. (2001). Language and power in blogging: A critical discourse analysis (vol. 20, pp. 282-286). Mindanao State University - Iligan Institute of Technology. 
Roy, A. (2001). The god of small things. New York: Harper Perennial Press.

Said, W. E. (1978). Orientalism. New York: Vintage books.

Schwar, H., \& Ray, S. (2005). A companion to postcolonial studies. New Jersey: Blackwell Publishing Ltd. https://doi.org/10.1002/9780470997024

Singh, S. (2011). The politics of transgression: History, society, and the individual in postcolonial literature. Student Pulse, 3, 1-2.

Wodak, R., \& Meyer, M. (2001). Methods for critical discourse analysis. London: Sage Publication ltd. https://doi.org/10.4135/9780857028020

\section{Copyrights}

Copyright for this article is retained by the author, with first publication rights granted to the journal.

This is an open-access article distributed under the terms and conditions of the Creative Commons Attribution license (http://creativecommons.org/licenses/by/4.0/). 